\title{
Optimising virtual team leadership in Global Software Development
}

Abstract: The globalisation of the software development industry has solved one set of problems and created a new set. Skills shortages in the host organisation can be solved by GSD, yet the effective management of virtual teams is a new challenge. This paper proposes a Process Reference Model (PRM) and Assessment Model for the leadership of project teams, including complex virtual teams. Using modelling techniques from Software Engineering, the Leadership PRM describes the attributes that a project manager should possess, and the activities they should perform if they are to be perceived by those around them as leaders. The developed model contains the essential leadership characteristics. Leadership is difficult to define since it is situationally expressed. The context determines the outward form that leadership takes in a given situation. A manager who innately embodies these essential leadership qualities will be perceived as a leader by those around them. Leadership is a skill that can be learned and developed over time to a higher level of competence. Managers coordinate the activities of team members in the pursuit of goals, while leaders extend this management capability by knowing how to motivate team members to want to do what it is the leader wants them to do.

\section{Introduction}

The general topic of leadership has been studied and discussed for a very long time, at least since the classical period of ancient Greece, as evidenced in the writings of 
Plato and others (Takala, 1998). In truth though, leadership studies almost certainly go back further than that to the even more ancient civilisations of the Nile Valley and Mesopotamia. These pre-date by several thousand years the classical period of Greece. Little written materials survive from these earlier civilisations, though their highly organised societies and engineering accomplishments point towards having possessed well-developed organisational skills which must have included leadership.

Despite the longevity and diversity of the literature on leadership, it is interesting that little consensus exists as to what constitutes true leadership. In recent times in the academic and practitioner literature, this question has been the subject of intense ongoing controversy among psychologists, sociologists, historians, political scientists and management researchers (Yukl, 1994). Despite this, no consensus has been reached on how leadership is defined. Operational definitions of leadership have much to do with the purpose and perspective of the researcher (Yukl, 1994). This view is confirmed by Stodgill (1974) in his comprehensive review of leadership studies which points out that there are almost as many definitions of leadership as there are persons who have attempted to define the concept.

It appears the combined efforts of researchers from sociology, psychology, political science, management etc have tended to cancel each other out. What follows is a sample of the opinions of some highly regarded scholars since the 1940's. Bernard (1948) considers that leadership studies has resulted in a great deal of dogmatically stated nonsense.

Burns (1978) believes that leadership is one of the most observed but least understood phenomena on earth. Bennis and Nanus (1985) observe that despite the thousands of empirical studies performed on leadership over the previous 75 years, no clear and unequivocal understanding has emerged as to how we can distinguish 
leaders from non-leaders. Yukl (1994) notes that leadership research has typically focussed on narrow issues with little effort made to integrate findings from different approaches and disciplines. No consensus exists as to what constitutes true leadership.

The lack of consensus on how to define leadership would seem to indicate that there are certain underlying character traits and activities (for example vision, integrity, resilience) that must be present if the quality of leadership is to be manifested in a given situation. But the way that these underlying traits are expressed will differ according to the needs of a given set of circumstances, hence the lack of consensus. The leadership model outlined in this chapter is derived from the set of essential underlying traits and activities from the broad literature, and distils them into a set of processes that can be applied in a broad range of situations.

\section{Distinguishing Managers from Leaders}

The differences between managers and leaders appear to be deeply embedded in the human psyche (Zaleznik, 2004). In his seminal paper on leadership, Zaleznik suggests that it is attitudes towards chaos and order that are the basis of the difference. A manager is more risk-averse, aiming for stability and control. Managers seek to solve problems as quickly as is practical, sometimes at the cost of understanding the nature of the problem fully. Leaders, by contrast, accept or at least tolerate chaos and lack of structure so that they might perceive and come to understand the underlying causes of situations. Uncertainty is the price that must be paid for the acquisition of a deep understanding. Zaleznik argues that leaders have more in common with creative thinkers such as artists and scientists than they do 
with managers. Leaders use their vision of future possibilities to proactively promote new directions while managers execute existing ways. Managers are more likely to adhere to orthodox approaches and resist new ways of doing things.

The ability to envisage a desirable future state and communicate it in a way that creates enthusiasm emerges from the literature as the pre-eminent leadership quality. This is nicely summed up in $19^{\text {th }}$ Century French writer Victor Hugo's most famous quote that one resists the invasion of armies; one does not resist the invasion of ideas. Such ideas fire the imagination of people and motivate them to realise the idea.

Takala (1998) suggests that what managers and leaders have in common is the ability to get things done. Takala distinguishes them by seeing managers as a kind of instructor who puts pieces together, and then manages the 'things'. A manager is primarily concerned with making an organisation function by evolving routines that serve the ongoing and sometimes changing purposes of the organisation. Takala (1998) observes that management is an activity typical in larger corporations. But there is leadership in every organisation, and not only in business organisations. A leader is a person who takes care of people and emphasises in his/her activities the social psychology of the organisation. Takala (1998) notes that this is the somewhat artificial but commonplace distinction made in the management literature between the two activities. He acknowledges however that a person who runs a business or leads an organisation acts situationally in both roles, sometimes a manager, sometimes a leader. 


\section{Leadership PRM}

The Leadership PRM was developed progressively using a re-iterative Design Research approach (Hevner, 2004) in which an initial prototype was developed based on the broad literature and reviewed in a series of design iterations over an 18 month period (a total of six reviews). The general method is shown below:

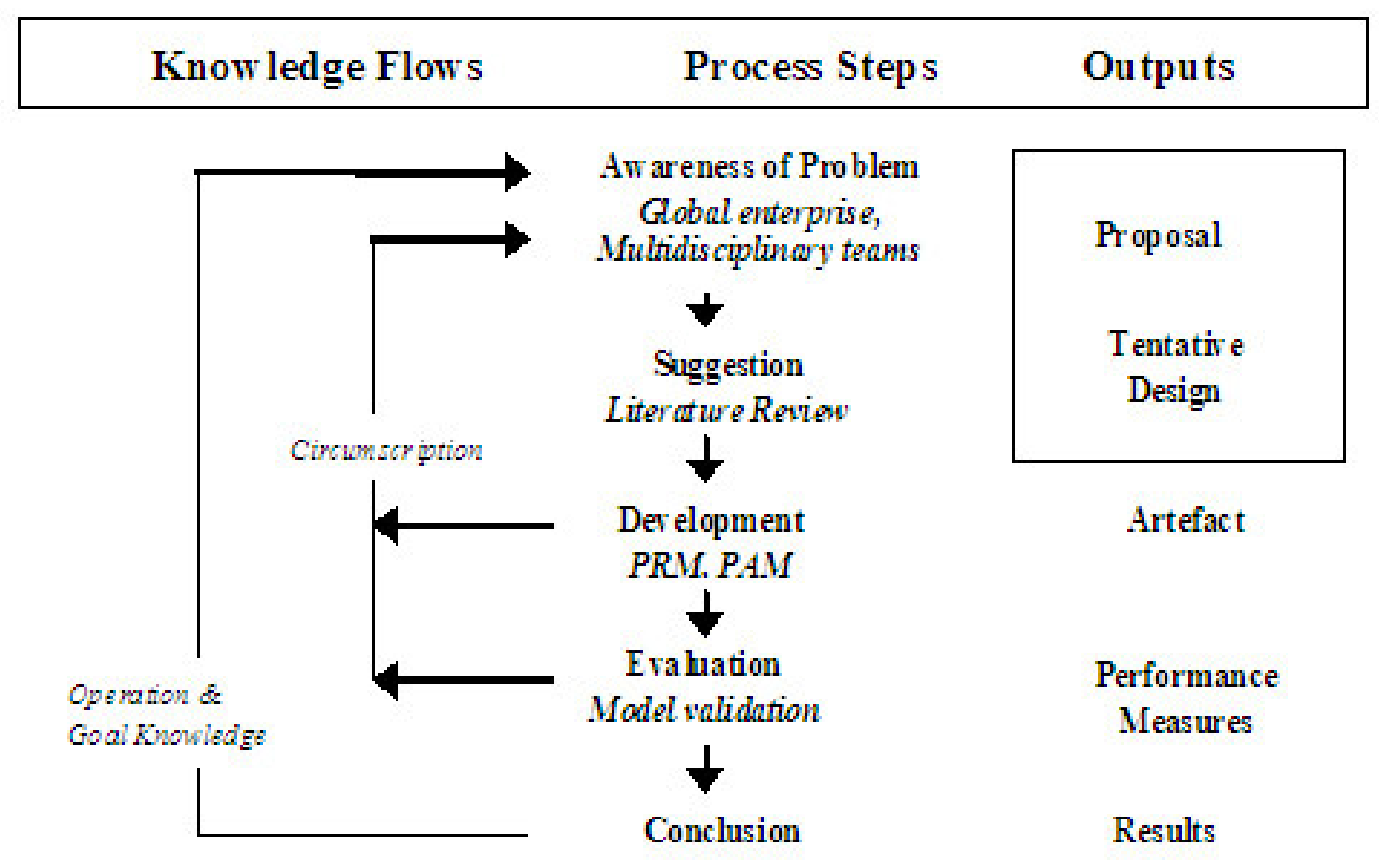

Figure 1: Methodology of Design Research for this project (Vaishnavi and Kuechler, 2004/5), (Vaishnavi and Kuechler, 2007), (Takeda et al 1990).

The reviews included the standard Process Refence Model-developer's method of practitioner and expert reviewers, plus an ISO/IEC 24774 conformance review to ensure the model met the requirements of that standard. The Process Reference Model (PRM) was also validated with Behavior Engineering (Dromey, 2006), a formal method for checking content and syntax for errors and ambiguities that was developed initially for validating software requirements for complex systems, but 
which has proven a highly effective method for validating PRMs (Tuffley and Rout, 2009).

Having passed through these six reviews, the V1.0 PRM was released and reviewed again by a focus group over a full day. The group comprised two practitioner project managers and two experts on process models in software engineering.

Data collection for the final iteration was by a focus group review whose terms of reference of this post-release review was to evaluate the efficacy of the leadership PRM, particularly in relation to (a) fitness for purpose, (b) organisation of and content of elements, and (c) what would make it more usable from a practitioner's point of view?

The focus group review was performed by a rigorous examination of the model over a six hour period. The group comprised four project managers, each of whom were actively coordinating the activities of a virtual team. Two of the project managers were from the IT projects segment of the higher education sector; the other two were from the systems development segment of the Australian Defense contractor sector. The group evaluated each process and associated outcomes for accuracy, understandability and comprehensiveness.

The focus group data was recorded into a pro-forma, as shown in the table below. The data included objective evidence that an outcome is actually being performed, and suggested improvements to the wording and content of the model. Yje information thus collected and consolidated was later incorporated into Version 1.1 of the model. Copies of draft V1.1 were later distributed to the participants for comment to validate that their input had been correctly interpreted. 


\subsection{Create and communicate a shared vision}

Purpose: to perceive and communicate a guiding principle/idea that captures the imagination of members to create a shared vision and inspire them with the enthusiasm to realise that vision. An aspect of charisma.

(Suggested change) Purpose: The purpose of the vision process is to create and communicate a shared vision in ways that inspires people to realize that vision

Outcomes: as a result of the successful implementation of creating a shared vision:

The leader perceives and formulates a unified vision of what is to be accomplished, ideally seen as an accomplished fact.

Activities and/or artefacts to support (bullet points are project manager's input $X 4)$ :

- Team Charter (Vision enunciated) Workshop

- Imperative objectives Website Comm thru mngt (Strategy -> Tactics -> Implement

- Project plan, Project launch presentation

- Plan w Snr Management

Leader communicates shared unified vision with team, ideally seen as an accomplished fact.

Activities and/or artefacts to support:

- Vision statement, Roadmap

- Yearly kick-off Quarterly review

- Team briefing

- Regular project meetings goals restated

Leader develops strong commitment to achieving vision, based on a sense of rightness and timeliness, such that they have sufficient resilience to overcome 
goal frustrating events

Activities and/or artefacts to support:

- $\mathrm{n} / \mathrm{a}$

- $\mathrm{n} / \mathrm{a}$

- Through briefings

- Regular meetings

Table 1: Focus group data collection pro-forma (sample)

Importantly for the purposes of this chapter, the clear consensus of the focus group was that the Leadership PRM would be a useful model for them to use. They each wanted a copy of the finalised V1.1 PRM for use in their own projects, which they were duly given. This feedback lends support to the argument that a PRM can be a useful and usable artefact for practicing project managers.

Also emerging from this first post-release review was a Process Assessment Model (PAM) based on the Leadership PRM. This PAM was developed in accordance with ISO/IEC 15504-1:2004 Parts 1 and 2,:

\section{Leadership Process Reference Model}

\begin{tabular}{cl}
\hline \multicolumn{1}{l}{ Individual Process Group (IND) } \\
\hline IND.1 & Vision \\
\hline IND.2 & Objective(s) \\
\hline IND.3 & Integrity \\
\hline IND.4 & Action-orientation \\
\hline IND.5 & Intelligence \\
\hline IND.6 & Individualized consideration \\
\hline IND.7 & Management-by-exception \\
\hline Team Process Group (TEM) & \\
\hline TEM.1 & Team structure \\
\hline
\end{tabular}




\begin{tabular}{cl}
\hline TEM.2 & Team requirements \\
\hline TEM.3 & Team recruitment \\
\hline TEM.4 & Team environment \\
\hline TEM.5 & Team formation \\
\hline TEM.6 & Team roles \\
\hline TEM.7 & Team rules \\
\hline TEM.8 & Team authority \\
\hline TEM.9 & Team performance management \\
\hline TEM.10 & Team development \\
\hline Organisation Process Group (ORG) \\
\hline ORG.1 & Team boundaries \\
\hline ORG.2 & Team collaboration \\
\hline ORG.3 & Team \& home organization balance \\
\hline
\end{tabular}

Table 2: Structure and content of PRM

It is important to note that the PRM can be used in three possible ways, (a) by project managers to evaluate their own practice, and engage in self-improvement by benchmarking against best-practice, (b) by organisations wishing to improve their internal management capability, and (c) by external agencies wishing to evaluate a potential supplier's management capability (the capability dimension is currently being developed).

Note: space does not permit the Informative Notes section to be included for every process in the table below. The Informative Notes for the first three processes are included as an indication. This is detailed practical advice on how to understand and apply the process and its associated outcomes. 
Individual Process Group (IND)

\begin{tabular}{|c|c|}
\hline Process ID & IND.1 Vision \\
\hline $\begin{array}{l}\text { Process } \\
\text { Name: }\end{array}$ & Vision \\
\hline $\begin{array}{l}\text { Process } \\
\text { Purpose: }\end{array}$ & $\begin{array}{l}\text { The purpose of the vision process is to create and communicate a shared } \\
\text { vision in ways that inspires people to realise that vision. }\end{array}$ \\
\hline $\begin{array}{l}\text { Process } \\
\text { Outcomes: }\end{array}$ & $\begin{array}{l}\text { As a result of successful implementation of the vision process: } \\
\text { 1) A vision of the goal(s) is created. } \\
\text { 2) The vision of the goal(s) is communicated to the team } \\
\text { 3) Commitment by team to the shared vision is gained }\end{array}$ \\
\hline
\end{tabular}

\section{Informative Notes}

Outcome 1 -- the vision of the goal is seen by the leader as achievable. The goals will still be abstract at this point. The goal(s) become concrete when translated into objective(s).

Outcome 2 - the shared vision should be communicated in a way that creates positive expectation and motivation among the team.

Outcome 3 - the way in which the shared vision of the abstract goal(s) is communicated should generate strong commitment to the achievement of the $\operatorname{goal}(\mathrm{s})$.

\section{General}

The shared vision is a clear and unambiguous expression of an envisioned future. It is the basis for a common understanding among stakeholders of the aspirations and governing ideals of the team in the context of that desired outcome.

Conditional on being effectively communicated by the leader to the team, the shared vision grounds the team's governing ideas and principles and allows for appropriate objectives to be derived.

Highly effective groups are often convinced they are engaged in important work, sometimes nothing short of being on a 'mission from God'. The work becomes an abiding obsession, a quest that goes well beyond mere employment. This intensely shared vision and sense of purpose endows cohesion and persistence. 
Creating and communicating a compelling vision of the future is an aspect of charisma; inspirational motivation, optimism, individualized consideration and contingent reward all appear to optimise team performance by creative a positive affective climate.

In summary when promulgating a shared vision, the following factors should be considered:

1. the project's objectives

2. the conditions and outcomes the project will create

3. interfaces the project needs to maintain

4. the visions created by interfacing groups

5. the constraints imposed by outside authorities (e.g., environmental regulations)

6. project operation while working to achieve its objectives (both principles and behaviors)

\section{Virtual and/or Integrated Teams}

In virtual environments the means by which the leader communicates the vision is of critical importance. Ideally, the virtual team should be brought to a single location for a team launch and team building exercise. Next best is high definition video-conferencing in conjunction with other channels of communication such as group-ware and email.

In integrated team environments, the complexity of the overall project team is likely to present practical difficulties in the means by which the leader's vision can be effectively communicated. As with virtual teams, the most effective method until fully immersive virtual environments are available is to bring everyone together at a project launch. Team bonding activities can and should be organised at the launch. If such an event is not practical, then effective use of the available communications technology must be made.

\section{Process ID IND.2 Objectives}
Process
Objectives
Name: 
The purpose of the objectives process is to create and communicate

Purpose: objective(s) based on the vision and derived goals.

Process

Outcomes:

As a result of successful implementation of the objectives process:

1) Practical objective(s) for goal(s) achievement are developed.

2) Positive expectation for achieving objective(s) is encouraged.

\section{Informative Notes}

Outcome 1 - from the shared vision and subsequent goals described in the previous Process a set of practically-worded objectives are developed that give the team a concrete set of outcomes to achieve.

Outcome 2 - having developed concretely-worded objectives, the leader generates in the team an optimistic mind-set and outlook towards the achievement of the objectives

\section{General:}

Once the leader has developed a compelling vision of what is to be accomplished, and managed to communicate it in a way that generates enthusiasm and commitment by the team, the leader, in consultation with team members if practical, develops a set of practically-worded objective(s) of what is to be achieved.

\section{Virtual and/or Integrated Teams}

In virtual and integrated team environments the consultation process may be more difficult but is nonetheless important. The leader needs to get team member buyin, or commitment, to the objectives, and this requires canvassing widely the views and attitudes of the team. The objectives must then be framed in a way that is consistent with those attitudes. The objectives are then fed back to the team. The team should recognise something of their input in what they receive.

Unquestioning obedience to orders coming down the chain of command is a necessity in the military, but is unlikely to work in a non-military environment, particularly where knowledge workers are concerned. Knowledge workers usually value themselves highly, often knowing more than the leader about their particular job. They require careful handling with an attitude of respect.

In virtual environments where the leader's presence is diminished, a good strategy 
is to lead by subtle influence -- allowing team members to exercise their sense of self-government, gaining influence by allowing them to feel influential.

Appearing to lack a compelling vision of the future will quickly undermine the confidence of the team for your leadership.

\begin{tabular}{|c|c|}
\hline Process ID & IND.3 Integrity \\
\hline Process Name: & Integrity \\
\hline $\begin{array}{l}\text { Process } \\
\text { Purpose: }\end{array}$ & $\begin{array}{l}\text { The purpose of the integrity process is to consistently act with integrity } \\
\text { and competence over time in pursuit of the vision. }\end{array}$ \\
\hline $\begin{array}{l}\text { Process } \\
\text { Outcomes: }\end{array}$ & $\begin{array}{l}\text { As a result of successful implementation of the integrity process: } \\
\text { 1) Integrity is consistently practiced. } \\
\text { 2) Competence is consistently exhibited. }\end{array}$ \\
\hline Process ID & IND.4 Action-orientation \\
\hline $\begin{array}{l}\text { Process } \\
\text { Name: }\end{array}$ & Action-orientation \\
\hline $\begin{array}{l}\text { Process } \\
\text { Purpose: }\end{array}$ & $\begin{array}{l}\text { The purpose of the action-orientation process is to be inclined towards } \\
\text { action and resilience. }\end{array}$ \\
\hline $\begin{array}{l}\text { Process } \\
\text { Outcomes: }\end{array}$ & $\begin{array}{l}\text { As a result of successful implementation of the action-orientation process: } \\
\text { 1) Objective-achieving behavior is decisively pursued. } \\
\text { 2) Objective-frustrating events are met with resilience. } \\
\text { 3) Viability of continuing pursuit of current objective(s) is evaluated. }\end{array}$ \\
\hline
\end{tabular}

\section{Informative Notes}

Outcome 1 - the leader consistently displays integrity, characterised by openness to truth, trustworthiness, and adherence to principle.

Outcome 2 - the leader manifests competence, characterised by technical and interpersonal skills, and advanced conceptual and reasoning skills. Competence in this context can be seen as an aspect of integrity in that it would be dishonest of an incompetent leader to act in a capacity that requires competence. 


\section{General}

Principle-centred leadership creates a climate in which team members can rely on a leader to act according to guiding principle rather than exigent circumstances. Involves doing the 'right thing' all of the time, even when it is easier not to under the circumstances.

Such a leader leads by example, leads by having an open, enlightened mind, leads by remaining true to him/herself. Such a person is a natural leader, one who is respected and whose example is followed. The antithesis is the tyrant who is closed-minded and who uses force to make people cooperate.

Such a leader acts from a sense of oneness with those being led. This sense of oneness is cultivated in a general sense by learning to recognise the interdependence and connectedness of the group members.

Such a leader avoids using unnecessary force to achieve ends, understanding that to do so create a new set of problems.

Self-worth is encouraged when the leader minimises the perceived distance between their sense of their own position and the position of those they lead. By identifying with the group members the leader can better understand the psychological needs of the members, and so their decisions are more aligned with those needs. By extension, an effective leader might go so far as to practice humility as a way of engendering the trust and respect of the group members. The interests of the members are naturally promoted because they are the interests of the leader as well. Therefore, effective leaders win the confidence of group members because the members sense the leader's identification with them.

\section{Virtual and/or Integrated Teams}

In virtual environments a leader's perceived integrity serves as a guiding and unifying influence to team members. Integrity engenders trust. Consistent integrity becomes something akin to a trusted presence in the mind of the team member, giving them a degree of certainty and helping to overcome the self-doubt that is sometimes inherent in an isolated work context.

In complex teams where members do not regularly encounter the leader, a similar benefit is observed. Integrity is defined in general as being whole and complete, with nothing missing. A leader who displays integrity is the embodiment of 
principled behavior; someone who can be relied upon to act in a principled way regardless of circumstance.

Integrity therefore calls for a high degree of moral courage, since from social psychology we know that people generally act according to who they are with rather than on principle, particularly if doing so will make them unpopular.

\begin{tabular}{|c|c|}
\hline Process ID & IND.5 Intelligence \\
\hline $\begin{array}{l}\text { Process } \\
\text { Name: }\end{array}$ & Intelligence \\
\hline $\begin{array}{l}\text { Process } \\
\text { Purpose: }\end{array}$ & $\begin{array}{l}\text { The purpose of the intelligence process is to apply appropriate cognitive } \\
\text { resources in the achievement of goals. }\end{array}$ \\
\hline $\begin{array}{r}\text { Process } \\
\text { Outcomes: }\end{array}$ & $\begin{array}{l}\text { As a result of successful implementation of the intelligence process: } \\
\text { 1) Original thinking in team-members is facilitated. } \\
\text { 2) Situations are realistically understood. } \\
\text { 3) Cause(s) of objective-achieving outcomes are generated. }\end{array}$ \\
\hline
\end{tabular}

\section{Process ID IND.6 Individualised consideration}

\begin{aligned} & $\begin{array}{r}\text { Process } \\ \text { Name: }\end{array}$ Individualised consideration \\ & \hline Process The purpose of the individualized consideration process is to convey to \\ & team-members their value as individuals. \\ & \hline Process As a result of successful implementation of the individualised \\ & Outcomes: consideration process: \\ & 1) Individual team-members are valued \\ & 2) Individual team-members are unified into team \\ & 3) Empathy towards individual team-members is practiced \\ & 4) Objective-achieving team behavior is rewarded \end{aligned}

Process ID IND.7 Management-by-exception

Process
Name:




\begin{tabular}{|c|c|}
\hline $\begin{array}{l}\text { Process } \\
\text { Purpose: }\end{array}$ & $\begin{array}{l}\text { The purpose of the management-by-exception process is to empower } \\
\text { team-members to act independently until and unless non-compliance of } \\
\text { standards has occurred. }\end{array}$ \\
\hline \multirow[t]{3}{*}{$\begin{array}{r}\text { Process } \\
\text { Outcomes: }\end{array}$} & $\begin{array}{l}\text { As a result of successful implementation of the management-by-exception } \\
\text { process: }\end{array}$ \\
\hline & 1) Independent team behavior that is objective-achieving is encouraged \\
\hline & 2) Non-objective-achieving team behavior is corrected \\
\hline
\end{tabular}

\section{Team Process Group (TEM)}

\begin{tabular}{|c|c|}
\hline Process ID & TEM.1 Team structure \\
\hline $\begin{array}{l}\text { Process } \\
\text { Name: }\end{array}$ & Team structure \\
\hline $\begin{array}{l}\text { Process } \\
\text { Purpose: }\end{array}$ & $\begin{array}{l}\text { The purpose of the team structure process is to create a flexible, goal- } \\
\text { oriented team structure. }\end{array}$ \\
\hline $\begin{array}{r}\text { Process } \\
\text { Outcomes: }\end{array}$ & $\begin{array}{l}\text { As a result of successful implementation of the team structure process: } \\
\text { 1) Objective-aligned team structure is established. } \\
\text { 2) Adaptable team structure is established. }\end{array}$ \\
\hline Process ID & TEM.2 Team requirements \\
\hline $\begin{array}{l}\text { Process } \\
\text { Name: }\end{array}$ & Team requirements \\
\hline $\begin{array}{l}\text { Process } \\
\text { Purpose: }\end{array}$ & $\begin{array}{l}\text { The purpose of the team requirements process is to allocate project } \\
\text { requirements to teams. }\end{array}$ \\
\hline $\begin{array}{l}\text { Process } \\
\text { Outcomes: }\end{array}$ & $\begin{array}{l}\text { As a result of successful implementation of the team requirements } \\
\text { process: } \\
\text { 1) Team structure is verified. } \\
\text { 2) Team sponsor(s) are appointed (Integrated) }\end{array}$ \\
\hline Process ID & TEM.3 Team recruitment \\
\hline $\begin{array}{l}\text { Process } \\
\text { Name: }\end{array}$ & Team recruitment \\
\hline
\end{tabular}




\begin{tabular}{|c|c|}
\hline $\begin{array}{l}\text { Process } \\
\text { Purpose: }\end{array}$ & $\begin{array}{l}\text { The purpose of the team recruitment process is to recruit persons with } \\
\text { skills appropriate to the achievement of project goals. }\end{array}$ \\
\hline $\begin{array}{r}\text { Process } \\
\text { Outcomes: }\end{array}$ & $\begin{array}{l}\text { As a result of successful implementation of the team recruitment process: } \\
\text { 1) Team members with appropriate skills are recruited. } \\
\text { 2) Virtual team members with appropriate skills are recruited (Virtual) } \\
\text { 3) Team leaders consistent with requirements are appointed (Integrated) }\end{array}$ \\
\hline Process ID & TEM.4 Team environment \\
\hline $\begin{array}{l}\text { Process } \\
\text { Name: }\end{array}$ & Team environment \\
\hline $\begin{array}{l}\text { Process } \\
\text { Purpose: }\end{array}$ & $\begin{array}{l}\text { The purpose of the team environment process is to establish the project's } \\
\text { work environment. }\end{array}$ \\
\hline $\begin{array}{r}\text { Process } \\
\text { Outcomes: }\end{array}$ & $\begin{array}{l}\text { As a result of successful implementation of the team environment } \\
\text { process: } \\
\text { 1) Appropriate infrastructure is provided. } \\
\text { 2) On-demand, synchronous, hi-resolution communications media is } \\
\text { provided (Virtual and/or Integrated). } \\
\text { 3) On-demand, synchronous, hi-resolution communications media is } \\
\text { used (Virtual and/or Integrated). }\end{array}$ \\
\hline Process ID & TEM.5 Team formation \\
\hline $\begin{array}{l}\text { Process } \\
\text { Name: }\end{array}$ & Team formation \\
\hline $\begin{array}{l}\text { Process } \\
\text { Purpose: }\end{array}$ & $\begin{array}{l}\text { The purpose of the team formation process is to constitute the team } \\
\text { structure. }\end{array}$ \\
\hline $\begin{array}{r}\text { Process } \\
\text { Outcomes: }\end{array}$ & $\begin{array}{l}\text { As a result of successful implementation of the team formation process: } \\
\text { 1) Team structure consistent with project requirements is established. } \\
\text { 2) Team charter consistent with requirements is established. } \\
\text { 3) Resources consistent with project requirements are allocated. }\end{array}$ \\
\hline
\end{tabular}

Process ID TEM.6 Team roles 


\begin{tabular}{|c|c|}
\hline $\begin{array}{r}\text { Process } \\
\text { Name: }\end{array}$ & Team roles \\
\hline $\begin{array}{l}\text { Process } \\
\text { Purpose: }\end{array}$ & The purpose of the team roles process is to define member roles. \\
\hline \multirow[t]{5}{*}{$\begin{array}{r}\text { Process } \\
\text { Outcomes: }\end{array}$} & As a result of successful implementation of the team roles process: \\
\hline & 1) Team member roles are understood. \\
\hline & 2) Contingency plans for team member absences are developed. \\
\hline & $\begin{array}{l}\text { 3) Singular roles per member in synchronous virtual environments are } \\
\text { defined (Virtual teams only) }\end{array}$ \\
\hline & $\begin{array}{l}\text { 4) Singular and/or multiple roles per member in asynchronous virtual } \\
\text { environments are defined (Virtual \& integrated teams). }\end{array}$ \\
\hline
\end{tabular}

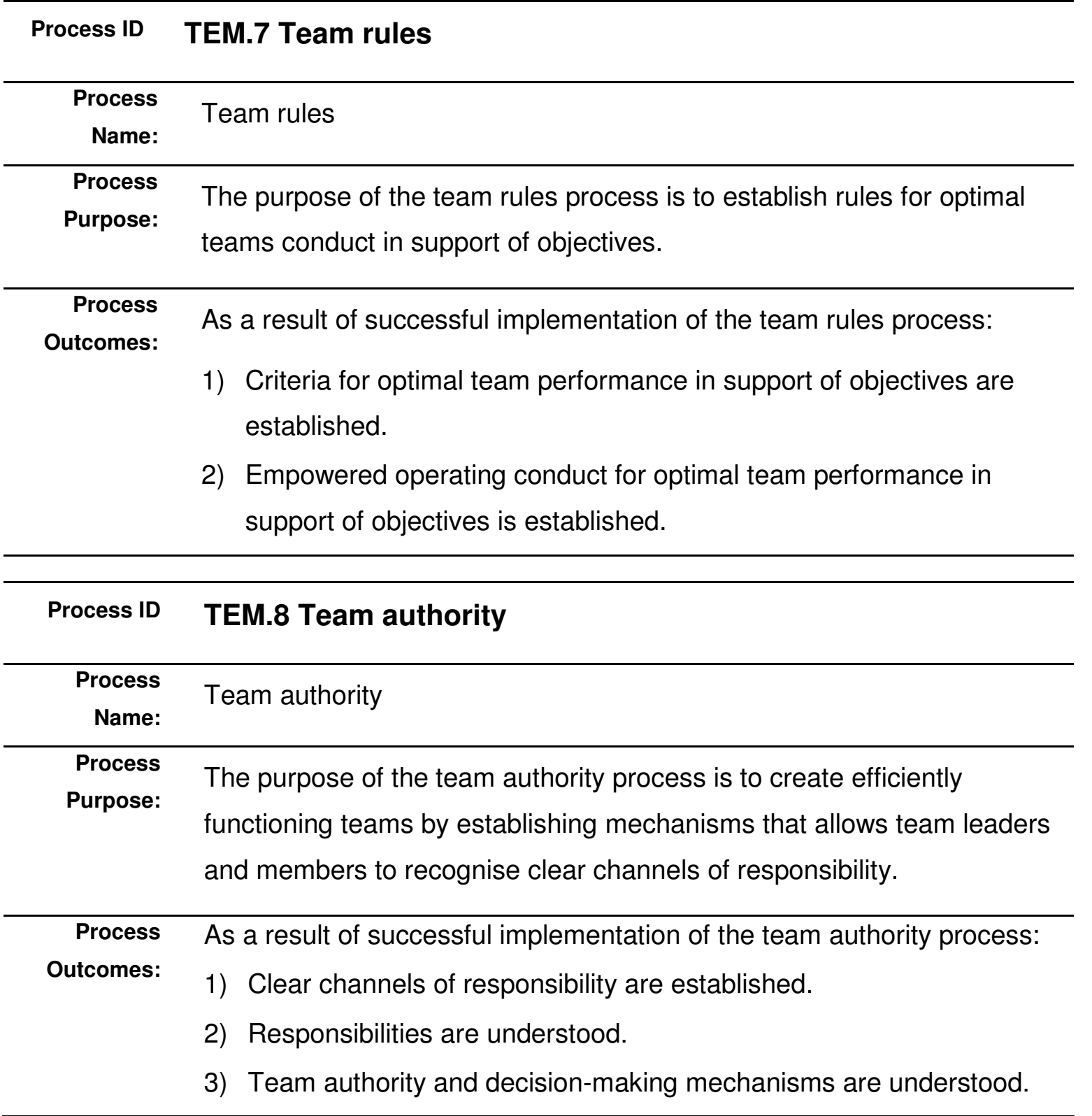


Process ID TEM.9 Team performance management

\begin{tabular}{|c|c|}
\hline $\begin{array}{r}\text { Process } \\
\text { Name: }\end{array}$ & Team performance management \\
\hline $\begin{array}{l}\text { Process } \\
\text { Purpose: }\end{array}$ & $\begin{array}{l}\text { The purpose of the team performance management process is to } \\
\text { manage team performance through the development of empowered } \\
\text { performance-management functions that allow team members to } \\
\text { manage themselves. }\end{array}$ \\
\hline $\begin{array}{r}\text { Process } \\
\text { Outcomes: }\end{array}$ & $\begin{array}{l}\text { As a result of successful implementation of the vision process: } \\
\text { 1) Self-managing performance functions are developed. } \\
\text { 2) High-capability self-managing performance functions for complex } \\
\text { asynchronous tasks are developed. } \\
\text { 3) Anticipatory self-management functions for proactive adaptation to } \\
\text { change are developed. } \\
\text { 4) Higher-capability self-managing performance functions across } \\
\text { complex team boundaries are developed. (Virtual \& integrated } \\
\text { teams) }\end{array}$ \\
\hline Process ID & TEM.10 Team development \\
\hline $\begin{array}{l}\text { Process } \\
\text { Name: }\end{array}$ & Team development \\
\hline $\begin{array}{l}\text { Process } \\
\text { Purpose: }\end{array}$ & $\begin{array}{l}\text { The purpose of the team development process is to establish team } \\
\text { development functions to promote productivity and coherence. }\end{array}$ \\
\hline $\begin{array}{l}\text { Process } \\
\text { Outcomes: }\end{array}$ & $\begin{array}{l}\text { As a result of successful implementation of the team development } \\
\text { process: } \\
\text { 1) Development practices for team coherence are established. } \\
\text { 2) Stable team membership is maintained. }\end{array}$ \\
\hline
\end{tabular}

\section{Organisational Process Group (ORG)}

\section{Process ID ORG.1 Team boundaries}

Process Team boundaries




\begin{tabular}{|c|c|}
\hline $\begin{array}{l}\text { Process } \\
\text { Purpose: }\end{array}$ & $\begin{array}{l}\text { The purpose of the team boundaries process is to manage team } \\
\text { boundaries. }\end{array}$ \\
\hline $\begin{array}{r}\text { Process } \\
\text { Outcomes: }\end{array}$ & $\begin{array}{l}\text { As a result of successful implementation of the team boundaries } \\
\text { process: } \\
\text { 1) Team boundaries are managed. } \\
\text { 2) Blended team culture is facilitated. }\end{array}$ \\
\hline Process ID & ORG.2 Team collaboration \\
\hline $\begin{array}{l}\text { Process } \\
\text { Name: }\end{array}$ & Team collaboration \\
\hline $\begin{array}{l}\text { Process } \\
\text { Purpose: }\end{array}$ & $\begin{array}{l}\text { The purpose of the team collaboration process is to ensure effective } \\
\text { collaboration among interfacing team elements. }\end{array}$ \\
\hline $\begin{array}{r}\text { Process } \\
\text { Outcomes: }\end{array}$ & $\begin{array}{l}\text { As a result of successful implementation of the team collaboration } \\
\text { process: } \\
\text { 1) Environment for collaboration is established. } \\
\text { 2) Environment for integrated and/or virtual team collaboration is } \\
\text { established (Virtual and Integrated Teams) }\end{array}$ \\
\hline
\end{tabular}

\section{Process ID ORG.3 Team \& home organisation balance}

\begin{aligned} $\begin{array}{r}\text { Process } \\ \text { Name: }\end{array} &$ Team and home organisation balance \\ \hline Process & $\begin{array}{l}\text { The purpose of the team and home organization process is to balance } \\ \text { team and home organization responsibilities. }\end{array} \\$\hline Process & As a result of successful implementation of the team and home \\ Outcomes: & $\begin{array}{l}\text { organization process: } \\ \text { 1) Guidelines for balancing team and home organization } \\ \end{array} \\ &$ 2) Gusponsibilities are established. \\ & responsibilities are maintained. \end{aligned}




\section{Comparison with other work in engineering management leadership}

In benchmarking the Process Reference Model against recent work done in engineering management, Polito and Martinich (2008) summarise leadership in engineering management as below. It will be seen that it is consistent with the PRM.

A. Initial Intensive Immersion Week Contents

i. Communication Skills for Engineering Leaders

ii. Building Collaborative Relationships

iii. Conflict Management

iv. Practical Negotiation Skills

v. Managing Innovation: Processes, Infrastructure, Competencies

vi. Risk Management

vii. Developing a Culture that Fosters Success

viii. Engineering Project Management

ix. Building Trust

x. Gaining Support for your Projects

xi. Strategic Planning

xii. Working with Others: Introduction to the Myers-Briggs Type Indicator

B. Follow On "Hot Topics" Topics

i. Managing Up

ii. Letting Go of Engineering Tasks: Maintaining

Competency while Shifting Focus

iii. Hiring and Retaining the Right People

iv. Diversity

v. Managing your Time

vi. Building Trust within Your Team 


\section{Discussion}

This paper explores the question; can the governance of virtual teams be optimized through the use of a Process Reference Model (PRM)?

Arguably, PRMs do have the potential to improve the effectiveness of virtual team governance. In this instance, this is achieved through giving project managers the means to develop their leadership capabilities to a higher level. The PRM discussed here can be applied in the broadest possible range of project management environments, in both the developed and developing worlds, thus allowing the developing world to participate in global virtual projects to a greater extent. This might then deliver a range of economic benefits for developing nations while being having the additional benefit of being environmentally sustainable through reducing the need for team members to travel and so produce carbon dioxide and consume other resources in the course of their travel.

The paper therefore examines the issue of effective governance and leadership in organisations. It argues the case that (a) leadership can be learned (as opposed to only having it through inheritance), and which can be formalized into a Process Reference Model, and (b) that such a PRM could have significant implications for organisations seeking to achieve an improved project management approach.

In support of the case that leadership can be learned is the extensive body of work by influential researchers on leadership like Warren Bennis (1994) and Peter Drucker (1996). This does not ignore the innate charisma of so-called 'born leaders', but makes the case that leadership can be cultivated and applied more effectively in a practical sense. 
It is clear that if an "implicit" concept such as Leadership can be re-conceptualized in this manner such that all of its underlying components can be analyzed and explored, then it would be possible to further re-conceptualize other 'implicit' concepts within the modern organization such as culture, innovation and various other hard-to-define capabilities. These important concepts must be understood if all of the important activities that occur within the modern organization are to be modelled and managed. In support of the case that leadership can be described as a process reference model is the work of process pioneer W. Edwards Deming who observed that if you cannot describe what you are doing as a process, you don't really know what you are doing (Deming, 1997). While the Leadership Process Reference Model conforms to the normative reference, qualifying it to be called a PRM, the broader, more organizationally-focused nature of this model suggests it might be best described as a new category of PRM, provisionally called a Reference Model for Organisational Behavior (RMOB). This topic will be explored in subsequent research.

A Leadership PRM developed by a rigorous Design Research process, tested in empirical trials and found to be useful by practitioners and experts is arguably a viable model. Strengthening this position is the draft Process Assessment Model that considers initially the process performance dimension, but which will be elaborated in on-going trials for the inclusion of the capability dimension.

The results so far have been encouraging. Not only is a Leadership PRM \& PAM useful its own right, but it also points to the possibility of developing other Process Reference Models and Assessment Models covering a range of organisational behaviors in a range of disciplines including but not limited to financial institutions and banks, automotive systems and software, aerospace systems and software, medical device systems and software, IT service management, test process 
improvement, small and very small enterprises. This would significantly extend the breadth of application of the standardized approach to process assessment.

\section{Conclusion}

Project Managers around the world have multiple challenges facing them as they move forwards into an uncertain future, not the least of which that of managing / leading complex virtual teams. It is increasingly likely that in a globalised future, projects will be done by virtual teams. Given the rising complexity of the world in general, such projects are also likely to be complex in nature, requiring a diversely talented multi-disciplinary team to perform it.

Arguably, one effective way to meet this challenge is with process models. The Engineering domain across its various disciplines has long made good use of process models to achieve consistent, high-quality outcomes; but such models have until recently been focussed on prescriptively describing how to do things. A new generation of process model is evolving in which organisational behavior is being described. Leadership, as difficult as the concept is to define, fits within this new category. The PRM discussed in this chapter is broadly applicable across sectors; it contains no engineering-specific processes. There is no reason why it could not be effectively applied to marketing and PR projects, or other non-engineering projects, since the content of the model is generic.

The difficulties of defining leadership notwithstanding, a Leadership PRM developed by a rigorous Design Research process, tested in trials and found to be useful by practitioners and experts is arguably a viable model that can be recommended for use by Project Managers. The feedback from the four post-release trials supports this view. 
The possibility of developing other Process Reference Models and associated Assessment Models that cover other organisational behaviors across a wide range of disciplines include but is not limited to financial institutions and banks, automotive systems and software, aerospace systems and software, medical device systems and software, IT service management, test process improvement, small and very small enterprises.

Note: readers wishing to obtain the latest version of the Leadership Process Reference Model and associated Assessment Model may email the author (d.tuffley@griffith.edu.au) to request.

\section{References}

Bennis, W. and Nanus, B., (1985). Leaders: the strategies for taking charge. New York, Haper and Row.

Bennis, W., (1994) On Becoming a Leader, What Leaders Read 1, Perseus Publishing, p 2.

Bernard, C.I. (1948). Organisations and Management. Cambridge, MA, Harvard University Press.

Burns, J.M., (1978). Leadership, New York, Harper and Row

Deming, W.E. (1997), Out of the Crisis, MIT Press, Cambridge MA.

Dromey, R.G. (2006). Climbing Over the 'No Silver Bullet' Brick Wall, IEEE Software, Vol. 23, No. 2, pp.118-120.

Drucker, P. (1996) Managing in a Time of Great Change, Butterworth Heinemann, London.

Herbsleb, J.D. Moitra, D. Global Software Development, IEEE Software, Vol 18, Issue 2, (16-20). (2001) 
Hevner, A., March, S., Park, J. and Ram, S. (2004). Design Science in Information Systems Research. MIS Quarterly 28(1): pp 75-105.

Hevner, A. (2007). A Three Cycle View of Design Science Research. Scandinavian Journal of Information Systems, 10(2) pp87-92.

ISO/EIA 12207 (1998) Standard for Information Technology-Software Life Cycle Processes. This Standard was published in August 1998.

ISO/IEC 15504 (2003) Information Technology: Process Assessment. Joint Technical Committee IT-015, Software and Systems Engineering. Part 2 Performing an Assessment. This Standard was published on 2 June 2005.

ISO/IEC TR 24774 (2007). Software and systems engineering -- Life cycle management -- Guidelines for process description. This Standard was published in 2007.

Polito, C., Martinich, L. (2008). Leadership: so easy even an engineer can do it! Engineering Management Conference, 2008. IEMC Europe 2008. IEEE International. Issue Date: 28-30 June 2008, pp 1 - 3.

Stodgill, R.M., (1974). Handbook of Leadership. New York Takala, T., (1998). Plato on Leadership. Journal of Business Ethics 17: pp. 785-798 Takeda, H., Veerkamp, P., Tomiyama, T., Yoshikawam, H. (1990). Modeling Design Processes. Al Magazine Winter: pp 37-48.

Tuffley, D., Rout, T (2009), Applying Behavior Engineering To Process Modelling, in Proceedings of the 1st Improving Systems and Software Engineering Conference (ISSEC), National Convention Centre, Canberra, Australia, 10-12 August 2009 Vaishnavi, V. K., Kuechler, W. (2004/5). Design Research in Information Systems. Last updated August $1^{\text {st }}$ 2009, accessed December $21^{\text {st }}$ 2010. URL: http://desrist.org/design-research-in-information-systems/ 
Vaishnavi, V.K., Kuechler, W. (2007) Design Science Research Methods and Patterns: Innovating Information and Communication Technology. CRC Press.

Yukl, G., (1994). Leadership in Organisations. Englewood Cliffs, N.J. Prentice-Hall

Zaleznik, A., (2004). Managers and Leaders: Are they different?, Harvard Business

Review, The Best of HBR edition, January. Article first published in 1977. 


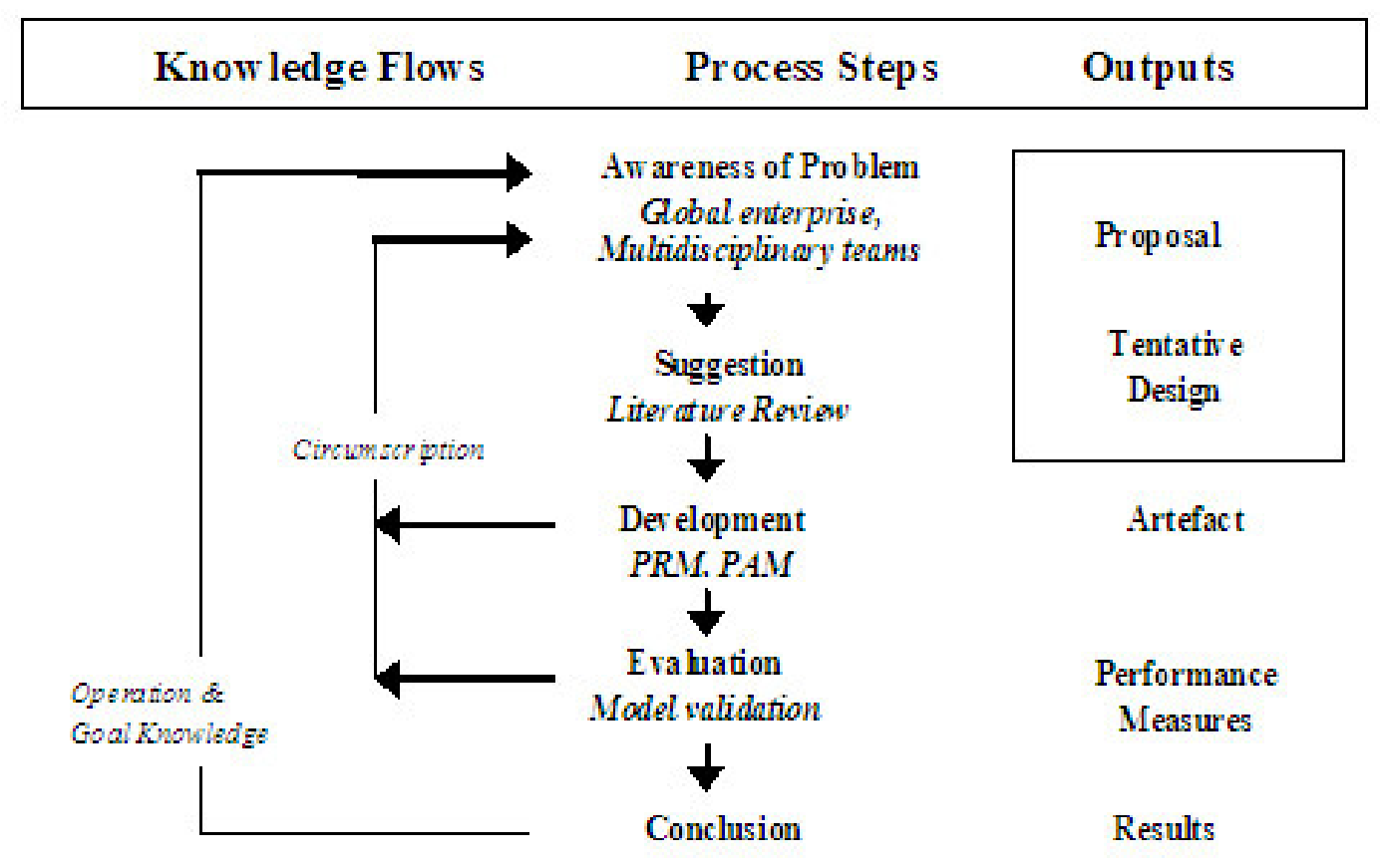

